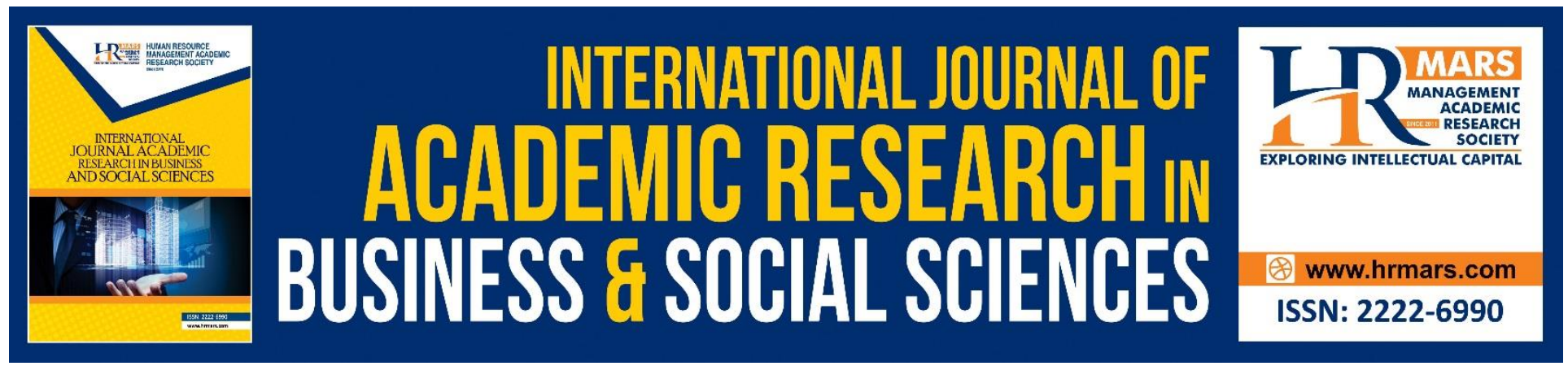

\title{
Being Popular on Facebook, are You Happy?
}

\author{
Jusang Bolong, Sri Azra Attan
}

To Link this Article: http://dx.doi.org/10.6007/IJARBSS/v10-i15/8232

DOI:10.6007/IJARBSS/v10-i15/8232

Received: 27 September 2020, Revised: 20 October 2020, Accepted: 12 November 2020

Published Online: 30 November 2020

In-Text Citation: (Bolong \& Attan, 2020)

To Cite this Article: Bolong, J., \& Attan, S. A. (2020). Being Popular on Facebook, are You Happy? International Journal of Academic Research in Business and Social Sciences, 10(15), 37-57.

\section{Copyright: (C) 2020 The Author(s)}

Published by Human Resource Management Academic Research Society (www.hrmars.com)

This article is published under the Creative Commons Attribution (CC BY 4.0) license. Anyone may reproduce, distribute, translate and create derivative works of this article (for both commercial and non-commercial purposes), subject to full attribution to the original publication and authors. The full terms of this license may be seen

at: http://creativecommons.org/licences/by/4.0/legalcode

Special Issue: Youth and Community Wellbeing: Issues, Challenges and Opportunities for Empowerment V1, 2020, Pg. 37 - 57

Full Terms \& Conditions of access and use can be found at http://hrmars.com/index.php/pages/detail/publication-ethics 


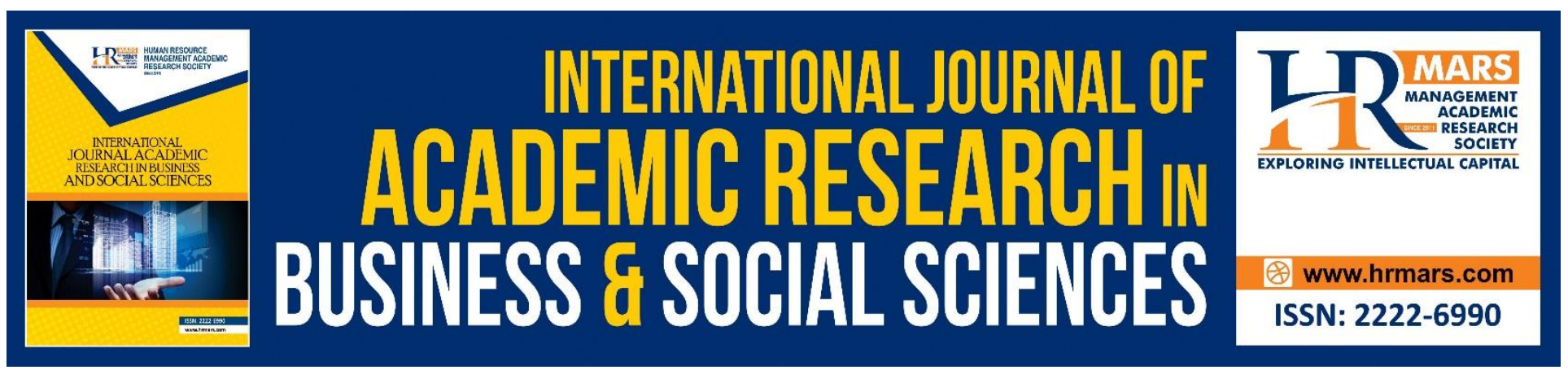

\title{
Being Popular on Facebook, are You Happy?
}

\author{
Jusang Bolong ${ }^{1}$, Sri Azra Attan² \\ ${ }^{1}$ Institute for Social Science Studies (IPSAS), Universiti Putra Malaysia, \\ 43400 UPM Serdang, Selangor, Malaysia, ${ }^{2}$ Faculty of Modern Languages and Communication, \\ Universiti Putra Malaysia, 43400 UPM Serdang, Selangor, Malaysia. \\ Email: jusang@upm.edu.my
}

\begin{abstract}
Popularity in cyberspace is more challenging compared to the Face-to-Face (FtF) environment since popularity plays a significant role in mediated-communication, where it affects the happiness in people's life. The objective of this study is to identify the relationship between popularity and life happiness amongst Facebook users. A quantitative survey was conducted by distributing a set of a questionnaire via a survey-development website to 402 Facebook users who were selected through snowball sampling technique. Results indicated that more popularity is shown by other Facebook users with lower uncertainty leading towards life unhappiness. Although the emotion of happiness in life occurs in FtF, online interaction could not make them feel the same way. Thus, the presence of mediated-communication is not taking over the FtF approaches. Future work should contribute towards the development of mediated-communication to better fit the dynamic nature of the interpersonal relationship and a worthier understanding of online human behavior.
\end{abstract}

Keywords: Popularity, Uncertainty, Life Happiness, Facebook, Mediated-Communication

\section{Introduction}

Many users of social media nowadays frequently display their identity on Facebook, regardless of verbal or non-verbal communication. One of the purposes of displaying one's identity is to get attention from others who followed them Facebook. When other Facebook users respond to identity disclosure, there is always a sense as a person who wants to be popular. Being popular is a form of self-satisfaction that becomes part of happiness in life. Life happiness refers to the individual's state of affairs who successfully manage time well and succeed in achieving balance in their whole life through daily activities from various aspects, including work, family, health, and social relations (Gropel, 2005). Life happiness is the psychological state of well-being, joy, and contentment, which evolved from the positive movement in life (Lyubomirsky, 2001) since the pursuit of happiness is an important life goal for every human being.

According to Scheibe et al. (2013), adolescents prefer to describe happiness in life as provisions of contentment, eagerness, and elevated level of encouragement, while senior citizens express happiness as a state of tranquility, relaxed, and low level of encouragement. This assertion is in order 
with Mogilner et al. (2010) which reported that adolescents prefer to relate happiness with enjoyment, while senior citizens prefer to describe happiness with tranquility. However, recent studies started to show an expansion; by examining subjective well-being through social media, such as Facebook, YouTube, Twitter, and Instagram. Besides, there is tremendous growth in benefiting mediated-communication for life happiness enhancement, like email techniques for better health quality (Wilson, 2015).

It was verified that the importance of life happiness in mediated-communication could strengthen the family bonds and a better academic achievement (Watson, 2009), where mediatedcommunication tools are needed for professional development in students' learning environments. Therefore, research has suggested that life happiness is not merely a magnitude of life impetus, e.g., environmental events or genetics issues. However, it is a crucial factor in life impact, e.g., positive career development, or great marriage, and family planning.

Dienlin et al. (2017) studied the effect of Social Networking Sites (SNS) communication on loneliness and life satisfaction. They found that both SNS and Face-to-Face (FtF) communication did not affect loneliness; however, life satisfaction is increased when people are communicating online, and this brings joy in people's life. The finding specified that communicating via SNS improves satisfaction for life happiness enhancement. However, the study was using a representative sample from Germany, and this makes a difference in the aspect of sample and population if it was to conduct in Malaysia.

Beaudry \& Pinsonneault (2010), in their research on Internet usage, had modeled a framework of emotions that categorize emotions into four different forms, namely challenge, achievement, loss, and deterrence emotions, which all related to motivation, and encouragement in the pursuit of happiness in life. The result indicated that happiness through enjoyment and excitement were related to Internet usage. This disclosure thus signifies that the emotions perceived by users at the implementation of the Internet application affect Internet usage, which is going forward for the achievement of happiness enhancement in life.

An online study by Utz and Beukeboom (2011) discovered that satisfaction, jealousy, SNS use, and need for popularity (the feeling of being attractive) predicted the emotional consequences of SNS use. As a result, self-esteem serves as a moderate effect on the SNS use and the need for popularity on SNS. They demonstrated that the need for popularity, SNS use for grooming, and satisfaction is positively related to the feeling of happiness in life. However, their study applied self-report measures, and so, social desirability might influence the results.

Sas et al. (2009) investigated the emotions and values of interactions among Facebook users. The outcomes suggested that the most unforgettable and essential experience with Facebook is everything about good emotion, delightful, motivation, and encouragement for users who read it, and this outcome is related to relationship attachment, entertainment, and happiness in life. They also reported that individuals who are frequently using Facebook to communicate with other users are more likely to provide emotional support to each other, given that the relationship that exists between them is closer than others. This line of reasoning increases their excitement when engaging in social media platforms online. Besides contemplating a constructive perception of Facebook, this 
finding illustrated the ability of Facebook to initiate a social support system virtually, where people can feel the happiness in life through their involvement in the Facebook community.

Kim and Lee (2011) investigated the Facebook path to happiness through the strategies of positive self-presentation by concentrating on the number of friends on Facebook, which could enhance users' happiness in life. By envisioning and showing a number of friends on Facebook, it reminds users of their proudly social networks. It later increases their confidence and self-esteem, which at last is beneficial to their level of happiness in life. The findings suggested that online friendships provide a new social climate for user's life happiness.

On that account, Chou \& Lim (2010) discovered that the utilization of an online social network is positively associated with the feeling of happiness in people's life. As a result, they succeed in constructing a framework for modeling happiness in online social networks, which was developed from six dimensions of happiness, containing self-acceptance, relationship with others, autonomy, personal growth, environmental mastery, and purpose of life. In social networks, someone who is in the middle of various social connections is referring to the notion that one feels happy and blissful. This line of argument shows that people surrounded by many happy people, and network-based people are more likely to be pleased with their future lives.

Lin \& Utz (2015) explored the emotion of reading the Facebook news feed and assessed the tie strength's role in predicting the feeling of happiness in life. They stated that reading a constructive news feed on Facebook brings to more positive emotions, e.g., the sense of joy and cheerfulness, as well as more deceptive emotions, e.g., the feeling of sadness, loneliness, envy, and boredom. The result presented that positive emotions are extra dominant while browsing Facebook than deceptive emotions. Moreover, tie strength serves as a moderate effect on the feeling of happiness after reading a Facebook news feed. This proclamation signifies that Facebook users were feeling happier when a useful post and updates appeared in the news feed from a close connection, rather than a weak tie. In other words, users will experience more happiness in life when receiving more headlines from their close friends on Facebook.

This discussion is parallel to the study conducted by Amichai \& Vinitzky (2010), which examined the behavior of users and its effect on the personality on Facebook. In their research, they detected a strong relationship between the behavior and the personality of Facebook users, which most of them were extraverts that tend to post more positive content on Facebook to show their happiness in life through enjoyment on their Facebook timeline. This statement implies the act and behavior of a person reflect its image and personality equally, where this experience brings peace of mind and serenity to the particular person.

In a related matter, Wang et al. (2014) examined the measurement of well-being by using the daily submission of millions of Facebook users. The subject matter to status updates typically includes temperaments, thoughts, and procedures, which revolve around everyday life, inspiration, life goals, or any topics the users wanted to spread to their Facebook friends. As a result, they declared that happier people tend to use more constructive words and lesser deceptive words in their status updates. Nevertheless, being visible to a high range of valuable status updates broadcasted by friends 
could result in an overall reduction in happiness. In contrast, waves of deceptive status updates could end in individuals feeling comparatively happier.

Wang (2013) explored the function of extraversion and openness to inspire the behavior of selfdisclosure, which affects the intensity of Facebook check-in. The study discovered that an absolute path from extraversion to self-disclosure and content sharing to Facebook check-in leads to the feeling of happiness in life. This motivation indicated that check-in is a crucial element to disclose the specific location for representing their social life, choices, lifestyle, and preferences, which allows them to have an improved self-image for life happiness enhancement.

Peterson et al. (2005) examined the associations between life satisfaction and orientation through an Internet survey. They endorsed three different directions to be happy, through pleasure, engagement, and meaning. Individuals who are low on all three orientations at once were described exceptionally low in life happiness. Therefore, these results pointed the predicament towards a particularity between the full life and the empty life of happiness.

Akin (2012) revealed that Internet addiction negatively predicted vitality and happiness. Vitality serves as a mediating effect on the relationship between Internet addiction and happiness in life. The study also presented that happiness in life is often connected with self-perception of well-being, satisfaction with life, satisfaction with relationships, constructive emotions, emotional intelligence, and self-improvement tendencies. However, the study did not deliberate on the relationship between Internet addiction and other psychological constructs of life happiness such as anxiety, trust, or uncertainty. Based on the literature review, it is possible that enhancement of life happiness indeed happens in virtual reality.

\section{Popularity and Life Happiness?}

For some, popularity is interpreted as widely liked or being well-liked by peers, others see it as being socially dominant, and some define popularity as accepted by one's peer group members (Gil et al., 2017). As popularity plays a role in mediated-communications, the approach of defining popularity on Facebook is not merely being liked by others but by the attribution of profile users; e.g., the length of timeline on Facebook (Zywica \& Danowski, 2008). Besides, several friends, comments, likes, and shares would be an indicator of being popular on Facebook. For example, the index of being popular on Facebook based on the average number of likes per post that is more than 1500, the average number of comments per post is 123 , and the average number of shares per post is 29 (Bonson \& Ratkai, 2013). The popularity of Facebook users is indicated by the network size, which rendering on the number of Facebook friends. However, the maximum number of friends allowed on Facebook is limited to 5000 friends only (Ekwok, 2017).

Scott (2014) investigated the role of online popularity and its effect on perceptions of targets' personality and appearance on Facebook. The findings showed that the number of friends, photos, and timeline activities influenced the popularity of Facebook profile owners. This condition indicated that network size and their active involvement on Facebook appears to be a reliable indicator of online popularity. The study also signified that popular users were appraised more appealing and attractive by other Facebook users, which led those who were attracted to popularity to be happier 
in their life. This clarification is due to popular users were perceived more positively compared to unpopular users because of their social activities on Facebook, which full of excitement and positive anticipation.

Converging on network size, Winter et al. (2011) examined the relationship status displayed on users' Facebook profiles and its relationship to self-presentation online. The results showed that the number of Facebook friends influences popularity, considering that the rating of popularity was more significant when the profile owners had a higher number of Facebook friends. The approach that profile owners formed impressions through self-presentation by creating positive images of themselves is one of the ways for other Facebook users to be attracted to them and later enhancing the feeling of happiness in their life.

Tong et al. (2008) examined the effect of network size on popularity in non-traditional ways, mainly on Facebook. They established that the profile owners' popularity was more significant when there was a higher number of Facebook friends. This statement is due to the profile owner was recognized as being popular when their profile includes a large number of friends and positive timeline postings, which have a severe effect on users' life happiness due to the attraction of popularity on the social network. This evidence signifies that the number of friends portray the size of one's network, and thus represents an indicator of online popularity.

In contrast, Antheunis and Schouten (2011) explored the effect of impressions on the online popularity of adolescents and found that the number of Facebook friends did not indicate popularity. This argument is caused by the implausible number of friends, which led to the interruption of apparent popularity to the excellent impression of the profile owner. This result indicated that the excess of friend connections raises suspicions about the originality of Facebook users' popularity and reflects on how a popular user on Facebook connects to others, e.g., the aggregate of people that one interacts for life happiness enhancement.

Hong et al. (2012) revealed that the similarity between one's self-presentation and the comment that one made leads other Facebook users to perceive Facebook's profile owner as more popular. Compared to when there is a dispute of dissimilarity, which contradicts from the self-presentation and the comments done. For example, if the timeline comments are negative, which are contrary to with profile photo, which is full of manners, users evaluate profile owners as unpopular. Thus, Facebook users with unattractive profile photos tend to be less popular, although they post a positive comment on their timeline wall. This circumstance generates the feeling of emptiness amongst Facebook users due to the identity conflict of targeted popular users that full of misperception and confusion, which possible to experience a lower level of happiness in life.

Zywica \& Danowski (2008) exposed that those who are extraverted with higher self-esteem expand their offline popularity by escalating it online. Within this study context, those who are introverted with low self-esteem and less popular offline struggle to be popular on Facebook. The decisions that they made for being popular influence those who are seeking for greater happiness by accelerating their popularity through Facebook to counteract their low popularity offline. This action implies that a fragment of happiness is under the influence of popular users through their daily activities and 
lifestyle. This reasoning indicated that the potential of mediated-communication plays a vital role in life happiness to reduce depressive symptoms and enrich global flourishing.

Chou and Edge (2012) assessed the effect of using Facebook on user's perceptions of other people's lives. They pointed out that popular users managed to portray themselves in a flattering way on their own Facebook profile. For example, positive messages and cheerful photos posted on Facebook give the users the impression that they are happy. This situation affected others' impressions in terms of seeing them as being popular on Facebook, which collectively lifting the element of greater happiness in users' life, due to the visualization of popular users are happier and regularly enjoying good experiences.

On that account, the premises and past studies of the scholars above raise the question regarding what extent popularity on Facebook is capable of making one's life happy? Thus, the objective of this study is to identify the relationship between popularity and life happiness amongst Facebook users.

\section{Methodology}

The data collection for this study was executed through a quantitative approach by using a surveydevelopment website, specifically http://bit.ly/2w4QXEd. The users of Facebook were chosen as the primary target population since Facebook is the world's largest and most popular online Social Networking Sites (SNS) (Mohammadi et al., 2020).

A non-probability sampling technique was implemented to generate a sample size for this study (Figure 1). It is difficult to identify the population in this study due to the rapid growth of New Communication Technology. Thus, this study was using an integrated purposive sampling method through a snowballing procedure by considering the characteristics of respondents to suit the purpose of the study. This procedure includes asking people who have contributed to a survey to recommend other people that they assume are attached to the research and would be willing to take part in the survey. Later, the sampling carried on until the required number of responses is achieved.

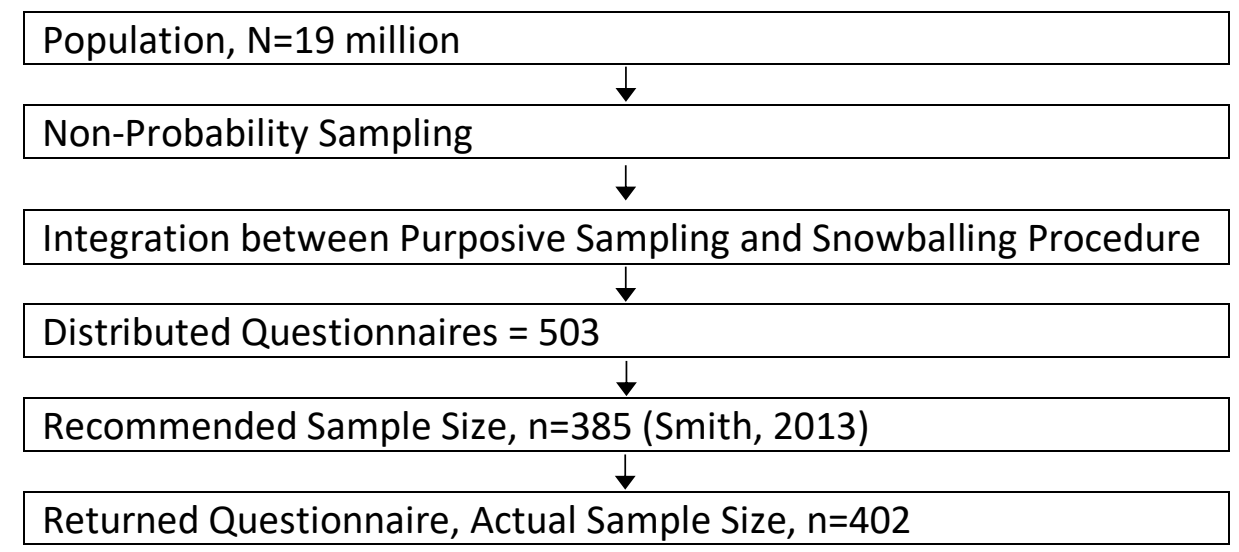

Figure 1: Details of Sampling

Within this study context, the relevant Facebook feature in structuring the snowballing procedure is a Facebook group. Thus, a researcher created the Facebook group based on specific interests, which includes the attraction to one specific local friend in the first year of involvement on Facebook, based 
on the initial relationship period is between 1-3 years (Baumeister \& Vohs, 2007). Then, a snowballing procedure was initiated by gathering respondents to one Facebook group via links to selected Facebook friends. Since the group administrator has access to control the content and the membership of the group, the administrator then progressively transmitted a message to up until the maximum of 5,000 group members.

Since 19 million Malaysian Facebook active users were in the sample frame, the minimum value that should be accounted for the distribution of the questionnaires was 385 respondents (Smith, 2013). The representation of an active user is a user who is online for at least three days within one week (Zhu et al., 2013).

This study was utilizing Descriptive Statistics and Inferential Statistics, which is Structural Equation Modeling (SEM). The statistical value in this data analysis was using Statistical Package for Social Science (SPSS) version 22.0 for Windows 10, and SmartPLS-SEM version 3.0 for Windows 10.

\section{Facebook Users and Its Usage}

Female users were more likely to use Facebook compared to male users. The judgment is due to female users are more intense contributors of content and significantly updating more status on Facebook than males. This verdict is because of male users were reported using interactive features on Facebook for the interpersonal communication and entertainment motives more than male users (Hunt, Atkin, \& Krishnan, 2012).

The majority of Facebook users are dominated by the digital-savvy generation, namely Gen- $X$ and Gen-Y, raised in the era when the Web was created that makes them constantly embraced the technology with excitement. This insight is caused by the fact that the millennial generation spent more hours, approximately between 20-21 hours of their time per day, for access to social media, compared to the Baby Boomers generation, which notched substantially lower in technology (Hansen \& Slagsvold, 2020).

Besides, single users were spending more time on Facebook, compared to married users. This result is driven by the occurrence that someone who uses Facebook multiple times per day gets about half the boost in total support that someone receives from being married or living with a partner. Therefore, single users get more support into perspective compared to those who already have their family, as Facebook enables individuals to increase the social and emotional support they may receive in case of need (Vitak et al., 2011).

Malay users were dominating Facebook compared to other races, followed by Chinese, Indian, and other races, namely Iban, Kadazan, Murut, and Bidayuh. The outcome is due to Malaysia as a multicultural country that established many races, with Malays constitute a majority of the population in Malaysia. At the same time, the Chinese and Indians are the minority within the total population (Haque et al., 2013). Malaysian Muslim users were using Facebook more, followed by Buddhists, Hindus, and Christians. It is important to note that in terms of religion aspect, Islam is the most widely practiced religion in Malaysia, with almost 62\% of the population being Muslims (Azzman \& Manaf, 2019). 
Sorted by educational background, those who have completed SPM/STPM represent the majority on Facebook. Therefore, the distribution suggested that the users with lower levels of education are more likely to use Facebook at the most, compared to those who have a higher level of education. This sighting is matched with the report by MCMC (2019) that the majority of the Internet users in Malaysia were holding SPM/SPVM, based on the educational attainment distribution of Internet users.

The majority of Facebook users were students, followed by users who served in the private sector and the government servant. However, the minority were running their own business in various fields such as restaurant, laundry, and cyber cafe, while some of them were housewives and jobless. The findings emerged due to the online social media is crucial for the academic community, as this new communication platform exhibits important impact on student motivation to learn, effective learning, and classroom climate. This figure is strengthened by Lytras and Garcia (2008), that social media creates an online social space where students can build and maintain social capital with others, as it is particularly important for them to build the social capital with the industry.

Almost half of Facebook users were using Facebook at home, followed by at work, while others were using Facebook at cafes, libraries, faculties, colleges, and hostels. Only the minority of them were paying for the service at a cyber cafe. This result is due to the caused that the venues for humancomputer interaction move beyond office walls and into places like homes since mobile tools such as Facebook asserted to support in-situ annotation in the home environment. Similarly, Facebook also provided an easy way for them to keep in touch with friends from home at no cost (Stern \& Taylor, 2007).

\section{Measurement of Variables}

The measurement of popularity was adapted from Facebook Popularity Scale (FPS) by Zywica \& Danowski (2008) as self-report measures to assess the popularity on Facebook. FPS primarily consists of six items that were created to measure online self-reported popularity. However, only three out of six items were selected to represent popularity on Facebook.

Another six items of popularity were adapted from the Popularity Scale (PS) by Santor et al. (2000) as a self-report measure to assess the popularity among younger adolescents. The PS consists of twelve items that were created to measure the popularity in the FtF condition. However, the PS's assessing approach was merely focusing on the popularity in the FtF condition. Thus, the initial measurement scale was adapted to make it relevant in online study. Out of 12 items of popularity, only six items were selected to represent popularity on Facebook. Three popularity items from FPS and six items from the PS were adapted due to its significance within this study's context. For instance, all popularity items were added "Based on his/her no. of friends, likes, comments, and shares on Facebook..." in front of each sentence.

Given that scale, one negatively worded item was reverse coded, out of nine items of popularity. For instance, the actual statement "I have hung out with popular people, so others would not think I was unpopular" was altered to "Based on his/her no. of friends, likes, comments, and shares on Facebook, he/she hung out with popular people, so others would not think he/she was unpopular". 
According to Zywica \& Danowski (2008), all the items on the FPS were checked for reliability by computing the Cronbach's (1951) alpha values, and the overall reliability for Facebook popularity had a coefficient of 0.78 and ranged from the lower 0.80 s to the upper 0.90 s in the most of previous studies. All the popularity items on FPS were using a five-point Likert-type response with the closedended questions in which the answer choices were ranging from 1 for very unpopular, 2 for unpopular, 3 for neutral, 4 for popular, and 5 for very popular. The five-point scale was not amended, utilized from the initial scale to maintain the scaling slope, except the scale description was changed to give more understanding to the respondents, which take less than three minutes to complete all the questions for this variable. Section B comprises six popularity's items by utilizing a five-point Likert scale of ordinal data, ranging from 1 for strongly disagree, 2 for disagree, 3 for neutral, 4 for agree, and 5 for strongly agree.

According to Santor et al. (2000), the Cronbach's (1951) alpha values were ranged from the lower 0.70s to the upper 0.90s for all items of the PS measurement. Initially, PS was using 5-point Likerttype response alternatives with the closed-ended questions in which the answer choices were ranging from 1 for strongly disagree, to 5 for strongly agree. Due to the context of this study, it was not modified, applied from the original scale, to maintain the scale slop. Section B comprises nine popularity's items by utilizing a five-point Likert scale of ordinal data, ranging from 1 for strongly disagree, 2 for disagree, 3 for neutral, 4 for agree, and 5 for strongly agree.

The distribution of the popularity level was described (Table 1) through the description of mean and SD. Then, the scores from the popularity variable were measured as the level of popularity. The measurement was done by dividing the total maximum score (no. of item multiply by scale 5), minus by the total of the minimum score (no. of item multiply by scale 1). The scores were divided by three levels, namely a high level, which ranged from 19 to 25, a moderate level, which ranged from 12 to 18, and a low level, which ranged from 5 to 11. The total calculation is the class interval for determining the range score for every level of popularity. The respondents' percentage for the level of popularity demonstrates that the respondents were located at the stated level of measurement. The maximum score explains that the level of popularity is high; meanwhile, the minimum score shows that the level of popularity is low.

Table 1: Description of Research Instrument

\begin{tabular}{llll}
\hline \hline Section & Variables & Total Items & Sources \\
\hline A & Profile of Respondents & 14 & Not applicable \\
B & Popularity & 9 & $\begin{array}{l}\text { Facebook Popularity Scale } \\
\text { by Zywica \& Danowski (2008) and } \\
\text { Popularity Scale (PS) by Santor et al. (2000) }\end{array}$ \\
C & Life Happiness & 29 & $\begin{array}{l}\text { Orientations to Happiness Scale } \\
\text { (OHS) by Peterson et al. (2005) }\end{array}$ \\
\hline
\end{tabular}

The measurement of life happiness was to assess happiness in a person's life amongst Facebook users. The life happiness measurement was adapted from the Orientations to Happiness (OTH), which was designed by Peterson et al. (2005) as self-report measures. The initial measurement was adapted to suit the online study applicability, particularly on Facebook. For instance, all items were added, 
"After my involvement on Facebook ..." in front of every sentence. Out of 36 items of Orientations to Happiness (OTH) measurement, only 29 items were selected to represent life happiness due to the suitability, and applicability of online study, especially on Facebook.

The Cronbach's (1951) alpha reliability for the OTH's assessing approach was 0.91 and ranged from the lower $0.75 \mathrm{~s}$ to the upper 0.90s in most of the previous studies. The initial 36 -item of the OTH measure required a respondent to answer on a five-point scale the degree to which the item applied, 1 for very much unlike me, to 5 for very much like me. For that reason, Section B also comprises of 29 life happiness' items of by utilizing a five-point Likert scale of ordinal data; which ranging from 1 for strongly disagree, 2 for disagree, 3 for neutral, 4 for agree, and 5 for strongly agree, which take less than 5 mins to complete this section.

The distribution of the life happiness level was described through the description of mean and SD. Then, the scores from the life happiness variable were measured as the level of life happiness. The measurement was done by dividing the total maximum score (no. of item multiply by scale 5), minus by the total of the minimum score (no. of item multiply by scale 1). The scores were divided by three levels, namely a high level, which ranged from 33 to 45, a moderate level, which ranged from 21 to 32, and a low level, which ranged from 9 to 20. The total calculation is the class interval for determining the range score for every level of life happiness. The respondents' percentage for the level of life happiness reveals that the respondents were located at the stated level of measurement. The maximum score explains that the level of life happiness is high; meanwhile, the minimum score shows that the level of life happiness is low.

\section{Findings}

One-third of Facebook users started using Facebook 1 - 5 years back, while over a quarter of them was using Facebook since 6 - 10 years ago. Almost a quarter of them was using Facebook for 11 years ago and more, while the least were using Facebook in the past one year ago and less. The result specified that more than half of them were using Facebook for quite an extended period of time. This situation is continuously happening due to social computing systems, which include SNSs, e.g., Facebook is increasingly becoming spaces where many users interact over long periods (Lampe et al., 2008).

Almost half of Facebook users were using Facebook seven times in a day and more, followed by 4 - 6 times a day, and twice or thrice daily, while none of them was using Facebook for one time and less daily. Students log onto FB several times per day to check and send messages to friends and viewing photos rather than all ten minutes at one time. This situation is seemingly due to Facebook users log onto FB multiple times per day to check and send messages to keep in touch and get to know others better, rather than doing all the Facebook activities at one time (Stern \& Taylor, 2007).

Half of Facebook users were using Facebook for 1 - 4 hour/hours daily, followed by one hour and less in a day, 4 - 8 hours in a day, and lastly 9 hours and more. This usage duration is equivalent to Stewart's (2016) assertion that Facebook users spend fifty minutes daily on Facebook on average. However, this discovery is far removed from Jafarkarimi et al. (2016)'s statement that, on average, $65 \%$ of users were using Facebook for more than seven hours daily since nowadays, SNSs such as Facebook has become a major communication vehicle in all societies. This contrast may be due to the job differences of them since most of them were students, which makes them need to focus more 
on their studies rather than being online, most of the time, to socialize with each other on Facebook. The view is parallel with Stern \& Taylor (2007) that the majority of students spent very little time on Facebook per day, with half of them logged onto Facebook for less than ten minutes a day, although Facebook was highly trafficked all day long.

The majority of Facebook users had local friends compared to international friends. Almost half of their friends were Malay, followed by Chinese and Indian. Lastly, their friends were mixed with all kinds of races. This finding may occur due to Facebook users who are in the same local network typically more likely to be friends with each other rather than those who are in the different local networks (Traud, Mucha \& Porter, 2012). Thus, the context of international friends in this study is for descriptive analysis only, and it was not referring to any long-time local friend that they attracted to, as they already understand the behavior of their friend in FtF interaction. Accordingly, the impression of the respondents in the first year of their involvement on Facebook is needed for data analysis.

There are several purposes for using Facebook. The majority of Facebook users in this study were using Facebook to remain in touch by communicating with new and existing friends, while some of them were looking for a love or life partner in a romantic relationship. Besides socializing within each other, they also gained knowledge from the information that they obtained during the conversation amongst Facebook users. Additionally, they were using Facebook to release the stress as well to kill their time at home. However, only a few of them were using Facebook for business purposes, such as online business and marketing. Therefore, it was understood that the purpose of using Facebook is generally for serving a wide range of interests. This statement was consistent with which supports the maintenance of pre-existing social relations, besides helping users to connect to others' profiles with shared interests, needs, political views, etc. (Mazman \& Usluel, 2010). As Lenhart and Madden (2007) postulated, users were using Facebook in their daily lives most for communicating with friends, making new friends, and sharing personal information and materials.

\section{Popularity}

Based on popular user's number of friends, likes, comments, and shares on Facebook, $25.13 \%$ of the respondents agreed that popular user would go out with certain people just because that people are popular $(\bar{x}=3.01)$. In comparison, $24.63 \%$ of them agreed that popular user changed the way he/she dress to be more popular ( $\bar{x}=3.16)$. Despite that, $28.36 \%$ of them agreed that popular user had been friends with some people, just because others liked them $(\bar{x}=3.21)$. Besides that, the highest mean for popularity $(\bar{x}=3.28)$ stated that popular user exaggerates or makes up information and puts it in his/her own Facebook profile. This breakthrough signified that popular user is always stepping out of the box in order to attract other Facebook users (Robertson, 2003), and that popularity on Facebook is clarified based on a number of friends, likes, comments, and shares, as advocated by (Fox \& Moreland, 2015), the number of friends, likes, comments and shares that one had on the network represents the level of user's popularity amongst the culture of a social network, like Facebook. Table 2 shows the distribution of popularity amongst Facebook users. 
INTERNATIONAL JOURNAL OF ACADEMIC RESEARCH IN BUSINESS AND SOCIAL SCIENCES

Vol. 10, No. 15, Youth and Community Wellbeing: Issues, Challenges and Opportunities for Empowerment V1. 2020, E-ISSN: 2222-6990 @ 2020 HRMARS

Table 2: Distribution of Popularity amongst Facebook users $(\mathrm{N}=402)$

\begin{tabular}{|c|c|c|c|c|c|c|c|c|}
\hline & \multirow{2}{*}{ Items } & \multicolumn{5}{|c|}{ Percentage (Frequency) } & \multirow{2}{*}{$\bar{x}$} & \multirow{2}{*}{ SD } \\
\hline & & 1 & 2 & 3 & 4 & 5 & & \\
\hline 1. & $\begin{array}{l}\text { Based on his/her no. of } \\
\text { friends, likes, } \\
\text { comments, and shares } \\
\text { on Facebook, he/she } \\
\text { exaggerates or makes } \\
\text { up information and } \\
\text { puts it in his/her } \\
\text { profile. }\end{array}$ & $\begin{array}{l}9.20 \\
(37)\end{array}$ & $\begin{array}{l}6.97 \\
(28)\end{array}$ & $\begin{array}{l}45.77 \\
(184)\end{array}$ & $\begin{array}{l}23.13 \\
(93)\end{array}$ & $\begin{array}{l}14.93 \\
(60)\end{array}$ & 3.28 & 1.09 \\
\hline 2. & $\begin{array}{l}\text { Based on his/her no. of } \\
\text { friends, likes, } \\
\text { comments, and shares } \\
\text { on Facebook, he/she } \\
\text { has been friends with } \\
\text { some people just } \\
\text { because others liked } \\
\text { them. }\end{array}$ & $\begin{array}{l}16.16 \\
(65)\end{array}$ & $\begin{array}{l}8.96 \\
(36)\end{array}$ & $\begin{array}{l}29.60 \\
(119)\end{array}$ & $\begin{array}{l}28.36 \\
(114)\end{array}$ & $\begin{array}{l}16.92 \\
(68)\end{array}$ & 3.21 & 1.29 \\
\hline 3. & $\begin{array}{l}\text { Based on his/her no. of } \\
\text { friends, likes, } \\
\text { comments, and shares } \\
\text { on Facebook, he/she } \\
\text { changed the way } \\
\text { he/she dress to be } \\
\text { more popular. }\end{array}$ & $\begin{array}{l}7.71 \\
(31)\end{array}$ & $\begin{array}{l}24.38 \\
(98)\end{array}$ & $\begin{array}{l}27.86 \\
(112)\end{array}$ & $\begin{array}{l}24.63 \\
(99)\end{array}$ & $\begin{array}{l}15.42 \\
(62)\end{array}$ & 3.16 & 1.18 \\
\hline 4. & $\begin{array}{l}\text { Based on his/her no. of } \\
\text { friends, likes, } \\
\text { comments, and shares } \\
\text { on Facebook, he/she } \\
\text { would go out with } \\
\text { certain people just } \\
\text { because they are } \\
\text { popular. }\end{array}$ & $\begin{array}{l}23.38 \\
(94)\end{array}$ & $\begin{array}{l}9.70 \\
(39)\end{array}$ & $\begin{array}{l}25.62 \\
(103)\end{array}$ & $\begin{array}{l}25.13 \\
(101)\end{array}$ & $\begin{array}{l}16.17 \\
(65)\end{array}$ & 3.01 & 1.39 \\
\hline 5. & $\begin{array}{l}\text { Based on his/her no. of } \\
\text { friends, likes, } \\
\text { comments, and shares } \\
\text { on Facebook, he/she } \\
\text { ignored certain } \\
\text { people to be more } \\
\text { popular. }\end{array}$ & $\begin{array}{l}23.38 \\
(94)\end{array}$ & $\begin{array}{l}17.91 \\
(72)\end{array}$ & $\begin{array}{l}20.65 \\
(83)\end{array}$ & $\begin{array}{l}20.65 \\
(83)\end{array}$ & $\begin{array}{l}17.41 \\
(70)\end{array}$ & 2.91 & 1.42 \\
\hline & & & & & Overal & & 3.11 & 1.27 \\
\hline
\end{tabular}

* Note: 1=Strongly Disagree, 2=Disagree, 3=Neutral, 4=Agree, 5=Strongly Agree 
As shown in Table 3, 32.3\% of the respondents were situated at a high level of popularity, whereas the majority (35.6\%) of the respondents were positioned at a moderate level of popularity. Nonetheless, $22.1 \%$ of them were located at a low level of popularity. The distribution shows that the popularity level amongst Facebook users is quietly even. Some Facebook users are attracted to a person who is popular amongst their Facebook friends, some were not, and this depends on the individual's needs. The needs of certain Facebook users might come from the desire to be in a peaceful mind, despite being in the chaotic of comments, likes, and shares from the popular Facebook users. Instead, some of them love to be recognized by having a greater number of friends, likes, comments, and shares on Facebook (Bucher, 2012). Table 3 demonstrates the distribution of level, score, percentage, mean, and SD of popularity amongst Facebook users.

Table 3: Level of Popularity amongst Facebook Users ( $N=402)$

\begin{tabular}{lllll}
\hline \hline Level of Popularity & Frequency & Percentage (\%) & $\overline{\mathbf{x}}$ & SD \\
\hline High $(19-25)$ & 130 & 32.3 & & \\
Moderate (12-18) & 143 & 35.6 & 15.6 & 2.3 \\
Low $(5-11)$ & 129 & 32.1 & & \\
\hline \hline
\end{tabular}

\section{Life Happiness}

After respondent's involvement on Facebook, $41.29 \%$ of them strongly agreed that they found beauty in some things $(\bar{x}=3.22)$, while $36.07 \%$ of the respondents strongly agreed that they experienced joy and elation ( $\bar{x}=3.24)$. Besides, after the respondent's involvement on Facebook, $30.60 \%$ of them strongly agreed that they always have a cheerful effect on others $(\bar{x}=3.30)$. In comparison, $30.35 \%$ of them strongly agreed that they usually have a good influence on events after their involvement on Facebook ( $\bar{x}=3.57)$. After their involvement on Facebook, almost half $(45.52 \%)$ of them agreed that they have warm feelings towards everyone $(\bar{x}=3.65)$, whereas $37.56 \%$ of them strongly agreed that life is very rewarding with the highest mean of life happiness $(\bar{x}=3.91)$. This aftermath conveyed that involvement on Facebook gives a tremendous change in people's life happiness (Kim \& Lee, 2011). As proposed by Lin \& Utz (2015), positive engagement on Facebook lead a life to be filled with positivity, and positive people aspire others to experience the feeling of happiness in their respective life. Table 4 shows the distribution of life happiness amongst Facebook users.

Table 4: Distribution of Life Happiness amongst Facebook users ( $N=402)$

\begin{tabular}{|c|c|c|c|c|c|c|c|c|}
\hline \multirow{2}{*}{ No. } & \multirow{2}{*}{ Items } & \multicolumn{5}{|c|}{ Percentage (Frequency) } & \multirow{2}{*}{$\overline{\mathbf{x}}$} & \multirow{2}{*}{ SD } \\
\hline & & 1 & 2 & 3 & 4 & 5 & & \\
\hline 1. & $\begin{array}{l}\text { After my } \\
\text { involvement on } \\
\text { Facebook, } \\
\text { I feel that life is } \\
\text { very rewarding. }\end{array}$ & $\begin{array}{l}0.00 \\
(0)\end{array}$ & $\begin{array}{l}8.71 \\
(35)\end{array}$ & $\begin{array}{l}30.10 \\
(121)\end{array}$ & $\begin{array}{l}23.63 \\
(95)\end{array}$ & $\begin{array}{l}37.56 \\
(151)\end{array}$ & 3.91 & 0.95 \\
\hline 2. & $\begin{array}{l}\text { After my } \\
\text { involvement on } \\
\text { Facebook, } \\
\text { I laugh a lot. }\end{array}$ & $\begin{array}{l}20.90 \\
(84)\end{array}$ & $\begin{array}{l}11.44 \\
(46)\end{array}$ & $\begin{array}{l}20.40 \\
(82)\end{array}$ & $\begin{array}{l}19.65 \\
(79)\end{array}$ & $\begin{array}{l}27.61 \\
(111)\end{array}$ & 3.90 & 1.01 \\
\hline
\end{tabular}


INTERNATIONAL JOURNAL OF ACADEMIC RESEARCH IN BUSINESS AND SOCIAL SCIENCES

Vol. 10, No. 15, Youth and Community Wellbeing: Issues, Challenges and Opportunities for Empowerment V1. 2020, E-ISSN: 2222-6990 @) 2020 HRMARS

\begin{tabular}{|c|c|c|c|c|c|c|c|c|}
\hline 3. & $\begin{array}{l}\text { After my } \\
\text { involvement on } \\
\text { Facebook, } \\
\text { I have a great } \\
\text { deal of energy. }\end{array}$ & $\begin{array}{l}15.92 \\
(64)\end{array}$ & $\begin{array}{l}16.17 \\
(65)\end{array}$ & $\begin{array}{l}21.14 \\
(85)\end{array}$ & $\begin{array}{l}21.14 \\
(85)\end{array}$ & $\begin{array}{l}25.62 \\
(103)\end{array}$ & 3.86 & 1.09 \\
\hline 4. & $\begin{array}{l}\text { After my } \\
\text { involvement on } \\
\text { Facebook, I can } \\
\text { fit in (find time } \\
\text { for) everything I } \\
\text { want to. }\end{array}$ & $\begin{array}{l}19.40 \\
(78)\end{array}$ & $\begin{array}{l}11.44 \\
(46)\end{array}$ & $\begin{array}{l}18.16 \\
(73)\end{array}$ & $\begin{array}{l}22.14 \\
(89)\end{array}$ & $\begin{array}{l}28.86 \\
(116)\end{array}$ & 3.66 & 1.04 \\
\hline 5. & $\begin{array}{l}\text { After my } \\
\text { involvement on } \\
\text { Facebook, } \\
\text { I have warm } \\
\text { feelings towards } \\
\text { everyone. }\end{array}$ & $\begin{array}{l}7.46 \\
(30)\end{array}$ & $\begin{array}{l}1.99 \\
(8)\end{array}$ & $\begin{array}{l}26.12 \\
(105)\end{array}$ & $\begin{array}{l}45.52 \\
(183)\end{array}$ & $\begin{array}{l}18.91 \\
(76)\end{array}$ & 3.65 & 1.21 \\
\hline 6. & $\begin{array}{l}\text { After my } \\
\text { involvement on } \\
\text { Facebook, I } \\
\text { usually have a } \\
\text { good influence } \\
\text { on events. }\end{array}$ & $\begin{array}{l}8.96 \\
(36)\end{array}$ & $\begin{array}{l}4.48 \\
(18)\end{array}$ & $\begin{array}{l}29.60 \\
(119)\end{array}$ & $\begin{array}{l}26.62 \\
(107)\end{array}$ & $\begin{array}{l}30.35 \\
(122)\end{array}$ & 3.57 & 1.23 \\
\hline 7. & $\begin{array}{l}\text { After my } \\
\text { involvement on } \\
\text { Facebook, } \\
\text { I always have a } \\
\text { cheerful effect on } \\
\text { others. }\end{array}$ & $\begin{array}{l}7.46 \\
(30)\end{array}$ & $\begin{array}{l}9.70 \\
(39)\end{array}$ & $\begin{array}{l}32.09 \\
(129)\end{array}$ & $\begin{array}{l}20.15 \\
(81)\end{array}$ & $\begin{array}{l}30.60 \\
(123)\end{array}$ & 3.30 & 1.48 \\
\hline 8. & $\begin{array}{l}\text { After my } \\
\text { involvement on } \\
\text { Facebook, } \\
\text { I experience joy } \\
\text { and elation. }\end{array}$ & $\begin{array}{l}0.00 \\
(0)\end{array}$ & $\begin{array}{l}4.48 \\
(18)\end{array}$ & $\begin{array}{l}36.57 \\
(147)\end{array}$ & $\begin{array}{l}22.89 \\
(92)\end{array}$ & $\begin{array}{l}36.07 \\
(145)\end{array}$ & 3.24 & 1.41 \\
\hline \multirow[t]{2}{*}{9.} & $\begin{array}{l}\text { After my } \\
\text { involvement on } \\
\text { Facebook, } \\
\text { I find beauty in } \\
\text { some things. }\end{array}$ & $\begin{array}{l}0.00 \\
(0)\end{array}$ & $\begin{array}{l}12.19 \\
(49)\end{array}$ & $\begin{array}{l}30.60 \\
(123)\end{array}$ & $\begin{array}{l}15.92 \\
(64)\end{array}$ & $\begin{array}{l}41.29 \\
(166)\end{array}$ & 3.22 & 1.49 \\
\hline & & & & & & Overal & 3.59 & 1.21 \\
\hline
\end{tabular}

* Note: 1=Strongly Disagree, 2=Disagree, 3=Neutral, 4=Agree, 5=Strongly Agree

As stated in Table 5, more than half (52.7\%) of the respondents were situated at a high level of life happiness, while the rest (28.1\%) were defined at a moderate level of life happiness. Nevertheless, 
only $19.2 \%$ of them were identified at a low level of life happiness. Therefore, this finding signifies that Facebook users were always sensed the feeling of happiness in their life. This statement is due to happiness is most of the important things that set individuals to be motivated in achieving their goals in their life, as stated by Siegert and Taylor (2004) regarding goal-setting and motivation. Table 5 displays the distribution of level, score, percentage, mean, and SD of life happiness amongst Facebook users.

Table 5: Level of Life Happiness amongst Facebook Users $(\mathrm{N}=402)$

\begin{tabular}{lllll}
\hline Level of Life Happiness & Frequency & Percentage (\%) & $\overline{\mathbf{x}}$ & SD \\
\hline High ( 33-45) & 212 & 52.7 & & \\
Moderate ( $21-32)$ & 113 & 28.1 & 33.3 & 2.9 \\
Low $(9-20)$ & 77 & 19.2 & & \\
\hline \hline
\end{tabular}

Hypothesis: As other Facebook user shows more popularity, the higher the life happiness

There is no significant relationship between popularity and life happiness $(t=1.645, p=0.101)$ amongst Facebook users (Table 6). Thus, the hypothesis is rejected; as other Facebook user shows more popularity, the higher the life happiness. This condition is probably due to people with a lot of Facebook friends that tend to have low self-esteem.

Table 6: Direct Relationship between Popularity and Life Happiness amongst Facebook users $(\mathrm{N}=402)$

\begin{tabular}{|c|c|c|c|c|c|}
\hline Hypothesis & Construct & $\begin{array}{l}t> \\
1.960\end{array}$ & $\begin{array}{l}p< \\
0.050\end{array}$ & Relationship & Decision \\
\hline $\begin{array}{l}\text { As other Facebook user } \\
\text { shows more } \\
\text { popularity, the higher the life } \\
\text { happiness. }\end{array}$ & $\mathrm{PP} \rightarrow \mathrm{LH}$ & 1.645 & 0.101 & $\begin{array}{l}\text { Not } \\
\text { Significant }\end{array}$ & Rejected \\
\hline
\end{tabular}

Lee et al. (2012) stated that people with most friends on Facebook experiencing low self-esteem because they are worried about their public perception. However, those self-conscious people compensate for their low self-esteem by trying to appear popular on Facebook. Instead, low selfesteem is a negative pattern of thoughts, pigeonholed by an individual's subjective perception that they are inadequate in countless facets of life ( $\mathrm{Ng} \&$ Page, 2019). Psychologists have recognized that self-esteem is an essential aspect of mental health and is relevant for many important life outcomes. For example, low self-esteem predicts antisocial behavior, delinquency, anxiety, and depression. In contrast, high self-esteem predicts happiness, better job performance, and academic achievement (Orth \& Robins, 2018).

It is noted that popularity is one of the factors that was influencing Facebook usage. The finding shows that there are some traits of popularity that initiates an individual to be attracted to another user, based on popular user's number of friends, likes, comments, and shares; as stated by Scott (2014) that the number of friends, photos, and timeline activities influenced the popularity of Facebook profile owners. This condition indicated that network size and their active involvement on Facebook appears to be a reliable indicator of online popularity. Moreover, some of the popular users on 
Facebook prefers to be acknowledged by having a greater number of friends, likes, comments, and shares on Facebook (Bucher, 2012).

This result also signifies that as more popularity is shown by other Facebook users, however not enhancing life happiness. Although popularity embodied experience tied to positive feelings, it does not enhance the life happiness amongst Facebook users. This fact is probably due to Facebook profile owners' popularity was associated with larger networks. Besides that, popular Facebook profile owners were also enhanced socializing and often linked to social events, which keeps them always in the bustle and does not have enough time to respond to every user who is attracted to them (Feiler \& Kleinbaum, 2015). This situation creates frustration amongst other Facebook users, and life happiness enhancement is not able to be continued. However, the uncertainty regarding the person that they are attracted to is reduced.

\section{Conclusion}

It is found that there is no significant relationship between popularity and life happiness amongst Facebook users. As more popularity is shown by other Facebook users, the lower the uncertainty; however, it is not enhancing the life happiness. Consequently, even though the emotion of happiness in life occurs in FtF, online interaction could not make them feel the same way. Thus, the presence of mediated-communication nowadays is not taking over the FtF approaches since such communication is meant for stabilizing and strengthening the process of developing a social relationship in a different context of time and space. In other words, even though users are popular on Facebook, it does not mean that they are happy in life. This is due to more popularity is shown by other Facebook users with lower uncertainty leading towards life unhappiness.

The implication of this study indicated that New Communication Technology through SNS is lack of with the value of humanity. People can be popular when they use Facebook; however, from the psychological view, they are still surrounded by feelings of unhappiness, which leads to depression, anxiety, low self-esteem, and aggression. Therefore, this study suggested that Facebook users need to limit and control their involvement in Facebook usage so that they will sense more feeling of tranquility and serenity. 


\section{References}

Akin, A. (2012). The Relationships Between Internet Addiction, Subjective Vitality, and Subjective Happiness. Cyberpsychology, Behavior and Social Networking, 15(8), 404-410.

Amichai, H., \& Vinitzky, G. (2010). Social network use and personality. Computers in Human Behavior, 26(6), 1289-1295.

Antheunis, M., \& Schouten, A. (2011). The effect of Other-Generated and System-Generated Cues on Adolescents' Perceived Attractiveness on Social Network Sites. Journal of Computer-Mediated Communication, 16(3), 391-406.

Azzman, T., \& Manaf, M. (2019). Celebrity-Fan Engagement on Instagram and Its Influence on The Perception of Hijab Culture Among Muslim Women in Malaysia. Jurnal Komunikasi: Malaysian Journal of Communication, 35(1), 286-302.

Baumeister, R. F., \& Vohs, K. D. (Eds.). (2007). Encyclopedia of Social Psychology. SAGE.

Beaudry, A., \& Pinsonneault, A. (2010). The other side of acceptance: studying the direct and indirect effect of emotions on information technology use. MIS Quarterly, 689-710.

Bonson, E., \& Ratkai, M. (2013). A set of metrics to assess stakeholder engagement and social legitimacy on a corporate Facebook page. Online Information Review, 37(5), 787-803.

Bucher, T. (2012). Want to be on the top? Algorithmic power and the threat of invisibility on Facebook. New Media \& Society, 14(7), 1164-1180.

Chou, G., \& Edge, N. (2012). "They are happier and having better lives than I am": the impact of using Facebook on perceptions of others' lives. Cyberpsychology, Behavior, and Social Networking, 15(2), 117-121.

Chou, A., \& Lim, B. (2010). A framework for measuring happiness in online social networks. Issues in Information Systems, 11(1), 198-203.

Dienlin, T., Masur, P., \& Trepte, S. (2017). Reinforcement or Displacement? The Reciprocity of FtF, IM, and SNS Communication and their effect on Loneliness and Life Satisfaction. Journal of Computer-Mediated Communication, 22(2), 71-87.

Ekwok, L. (2017). Facing Criminality on Facebook. People: International Journal of Social Sciences, 3(1), 787-805.

Feiler, D., \& Kleinbaum, M. (2015). Popularity, Similarity, and Network Extraversion Bias. Psychological Science, 26(5), 593-603.

Fox, J., \& Moreland, J. (2015). The Dark Side of Social Networking Sites: An Exploration of the Relational and Psychological Stressors Associated with Facebook Use and Affordances. Computers in Human Behavior, 45, 168-176.

Gil, L. A., Gil, L. A., Dwivedi, A., Dwivedi, A., Johnson, L. W., \& Johnson, L. W. (2017). Effect of popularity and peer pressure on attitudes toward luxury among teens. Young Consumers, 18(1), 84-93.

Gropel, P. (2005). On the theory of life balance: The relation to subjective well-being and the role of self-regulation (Doctoral Dissertation, University of Osnabruck).

Hansen, T., \& Slagsvold, B. (2020). An "Army of Volunteers"? Engagement, Motivation, and Barriers to Volunteering among the Baby Boomers. Journal of Gerontological Social Work, 1-19.

Haque, A., Momen, A., Sultana, S., \& Yasmin, F. (2013). Effectiveness of Facebook towards online brand awareness: a study on Malaysian Facebook users' perspective. Australian Journal of Basic and Applied Sciences, 7(2), 197-203. 
Herring, S., Stein, D., \& Virtanen, T. (Eds.). (2013). Pragmatics of Computer-Mediated Communication (Vol. 9). Walter de Gruyter.

Hong, S., Tandoc, E., Kim, A., Kim, B., \& Wise, K. (2012). The real you? The role of visual cues and comment congruence in perceptions of social attractiveness from Facebook profiles. Cyberpsychology, Behavior and Social Networking, 15(7), 339-344.

Hunt, D., Atkin, D., \& Krishnan, A. (2012). The influence of computer-mediated communication apprehension on motives for Facebook use. Journal of Broadcasting \& Electronic Media, 56(2), 187-202.

Jafarkarimi, H., Sim, A., Saadatdoost, R., \& Hee, J. (2016). Facebook addiction among Malaysian students. International Journal of Information and Education Technology, 6(6), 465-469.

Kim, J., \& Lee, J. (2011). Facebook Paths to Happiness: effect of the Number of Facebook Friends and Self-Presentation on Subjective Well-Being. CyberPsychology, Behavior, and Social Networking, 14(6), 359-364.

Lampe, C., Ellison, N. B., \& Steinfield, C. (2008, November). Changes in use and perception of Facebook. In Proceedings of the 2008 ACM Conference on Computer Supported Cooperative Work (pp. 721-730). ACM.

Lee, J., Moore, D., Park, E., \& Park, S. (2012). Who wants to be "friend-rich"? Social compensatory friending on Facebook and the moderating role of public self-consciousness. Computers in Human Behavior, 28(3), 1036-1043.

Lin, R., \& Utz, S. (2015). The emotional responses of browsing Facebook: Happiness, envy, and the role of tie strength. Computers in Human Behavior, 52, 29-38.

Lenhart, A., \& Madden, M. (2007). Social Networking Websites and Teens: An Overview. Pew Internet \& American Life Project.

Lytras, M. D., \& Garcia, R. (2008). Semantic Web applications: a framework for industry and business exploitation-What is needed for the adoption of the Semantic Web from the market and industry. International Journal of Knowledge and Learning, 4(1), 93-108.

Lyubomirsky, S. (2001). Why are some people happier than others? The role of cognitive and motivational processes in well-being. American Psychologist, 56(3), 239.

Mazman, S., \& Usluel, Y. (2010). Modeling educational usage of Facebook. Computers \& Education, 55(2), 444-453.

MCMC. (2019). Malaysian Communications and Multimedia Commission. Internet Users Survey, 2018. $\begin{array}{llll}\text { Retrieved July } \quad 12, & \text { 2019, from }\end{array}$ https://www.mcmc.gov.my/skmmgovmy/media/General/pdf/Internet-Users-Survey-2018.pdf

Mohammadi, E., Gregory, K. B., Thelwall, M., \& Barahmand, N. (2020). Which health and biomedical topics generate the most Facebook interest and the strongest citation relationships?. Information Processing \& Management, 57(3), 1-29.

Mogilner, C. (2010). The pursuit of happiness, time, money, and social connection. Psychological Science, 21(9), 1348-1354.

Ng, J., \& Page, A. (2019). Revised Reality Therapy: A New Intervention to Help Boost Self-Esteem in Malaysian Secondary Schools. In Multicultural Counseling Applications for Improved Mental Healthcare Services (pp. 64-83).

Orth, U., \& Robins, R. (2018). Development of Self-Esteem across the Lifespan. Handbook of Personality Development, 328. Guilford Publications. 
Peterson, C., Park, N., \& Seligman, M. E. (2005). Orientations to happiness and life satisfaction: The full life versus the empty life. Journal of Happiness Studies, 6(1), 25-41.

Phua, J., Jin, S., \& Kim, J. (2017). Uses and gratifications of Social Networking Sites for bridging and bonding social capital: A comparison of Facebook, Twitter, Instagram, and Snapchat. Computers in Human Behavior, 72, 115-122.

Robertson, J. W. (2003). Stepping out of the box: Rethinking the failure of ICT to transform schools. Journal of Educational Change, 4(4), 323-344.

Santor, D., Messervey, D., \& Kusumakar, V. (2000). Measuring peer pressure, popularity, and conformity in adolescent boys and girls: Predicting school performance, sexual attitudes, and substance abuse. Journal of Youth and Adolescence, 29(2), 163-182.

Sas, C., Dix, A., Hart, J., \& Su, R. (2009). Emotional experience on Facebook site. Conference on Human Factors in Computing Systems, 27, 4345-4350.

Scheibe, S., English, T., Tsai, J., \& Carstensen, L. (2013). Striving to Feel Good: Ideal Affect, Actual Affect, and Their Correspondence across Adulthood. Psychology and Aging, 28(1), 160-71.

Scott, G. G. (2014). More than friends: Popularity on Facebook and its role in impression formation. Journal of Computer-Mediated Communication, 19(3), 358-372.

Siegert, R. J., \& Taylor, W. J. (2004). Theoretical aspects of goal-setting and motivation in rehabilitation. Disability and Rehabilitation, 26(1), 1-8.

Stern, L. A., \& Taylor, K. (2007). Social networking on Facebook. Journal of the Communication, Speech \& Theatre Association of North Dakota, 20(2007), 9-20.

Stewart, J. B. (2016). Facebook has 50 minutes of your time each day. It wants more. The New York Times, 5.

Tong, S., Heide, V., Langwell, L., \& Walther, J. (2008). Too much of a good thing? The relationship between number of friends and interpersonal impressions on Facebook. Journal of Computer-Mediated Communication, 13(3), 531-549.

Traud, A. L., Mucha, P. J., \& Porter, M. A. (2012). Social structure of Facebook networks. Physica A: Statistical Mechanics and its Applications, 391(16), 4165-4180.

Utz, S., \& Beukeboom, C. (2011). The Role of Social Network Sites in Romantic Relationships: effect on Jealousy and Happiness. Journal of Computer-Mediated Communication, 16(4), 511-527.

Utz, S., Muscanell, N., \& Khalid, C. (2015). Snapchat elicits more jealousy than Facebook: A comparison of Snapchat and Facebook use. Cyberpsychology, Behavior, and Social Networking, 18(3), 141-146.

Vitak, J., Ellison, N., \& Steinfield, C. (2011). The ties that bond: Re-examining the relationship between Facebook use and bonding social capital. In $201144^{\text {th }}$ Hawaii International Conference on System Sciences (pp. 1-10). IEEE.

Wang, N., Kosinski, M., Stillwell, D., \& Rust, J. (2014). Can well-being be measured using Facebook status updates? Validation of Facebook's Gross National Happiness Index. Social Indicators Research, 115(1), 483-491.

Wang, S. (2013). "I share, therefore I am": Personality traits, life satisfaction, and Facebook checkins. Cyberpsychology, Behavior and Social Networking, 16(12), 870-877.

Watson, D. (2009). The Question of Morale: Managing Happiness and Unhappiness in University Life: Searching for Happiness in University Life. McGraw-Hill Education (UK). 
Wilson, E. V. (2015). Understanding how message receivers' communication goals are applied in online persuasion. In International Conference on Persuasive Technology (pp. 39-50). Springer International.

Winter, S., Haferkamp, N., Stock, Y., \& Kramer, N. C. (2011). The Digital Quest for Love - The Role of Relationship Status in Self-Presentation on Social Networking Sites. Journal of Psychological Research in Cyberspace, 5(2), Article 3. Retrieved from https://cyberpsychology.eu/article/view/4247/3293.

Zhu, Y., Zhong, E., Pan, S., Wang, X., Zhou, M., \& Yang, Q. (2013). Predicting User Activity Level in Social Networks. In Proceedings of the $22^{\text {nd }}$ ACM International Conference on Information \& Knowledge Management (pp. 159-168).

Zywica, J., \& Danowski, J. (2008). The faces of Facebookers: Investigating social enhancement and social compensation hypotheses; predicting Facebook ${ }^{\mathrm{TM}}$ and offline popularity from sociability \& selfesteem and mapping the meanings of popularity with semantic networks. Journal of ComputerMediated Communication, 14(1), 1-34. 